\title{
Availability and Utilization of Instructional Materials for Teaching of Indigenous Language (IGBO) in Public Junior Secondary Schools in Ebonyi State, Nigeria
}

\author{
Nwigwe Nwakaego \\ Department of Arts and Social Science Education, Ebonyi State University, Abakaliki
}

\begin{abstract}
This study was carried out with the aim of ascertaining the availability and utilization of instructional materials for teaching of indigenous language (Igbo) in Public Junior Secondary Schools in Ebonyi State. The study adopted the descriptive survey research design. Two research questions guided the study. The population of the study comprised all the fifty two (52) Igbo language teachers in Afikpo Education Zone of Ebonyi State. The research instrument used for the data collection was a questionnaire developed by the researcher and validated by three experts. The reliability of the instrument was established using Pearson product moment correlation. The reliability coefficient of the instrument was found to be 0.80 . The data analysis was done using percentages, mean and standard deviation. The results of the findings showed that instructional materials are available and adequate for teaching Igbo language in Public Secondary Schools in Ebonyi State. The study further revealed that most of these instructional materials were either lowly utilized or not utilized in teaching Igbo Language. The researcher made the following recommendations based on the findings. The Igbo language teachers should effectively utilize the instructional materials such as, audio,visual and audio-visual materials for teaching of the language. Secondly, Igbo language teachers should be encouraged to go for professional development through seminars, in-service training programs, seminars and workshops, in order to be effective in the utilization of instructional materials for effective teaching and learning of Igbo language.
\end{abstract}

Keywords: Instructional material, Availability, Utilizations, Igbo Language.

DOI: $10.7176 / \mathrm{JEP} / 11-5-03$

Publication date: February $29^{\text {th }} 2020$

\section{Introduction}

Language is not only a medium of communication but also a matrix through which the culture, values norms and mores of a people are transmitted. Language is one of the most enduring artifacts of culture. It serves as an important element of human identity and evaluation of traditional societies and therefore plays a crucial role in the overall human and social existence. Igbo is one of the indigenous Nigerian Languages that is spoken by over 16 million $(16,381,729)$ people in the South East Nigeria (Federal Republic of Nigeria, 2007). Igbo Language is the supreme expression of the cultural heritage of the people of the South East Nigeria. Without the language, it would be difficult to talk about culture revival, research, teaching and learning of Igbo in schools or in the world. It is the language of tradition and cultural communication. It is learned at home, schools, and colleges and in tertiary institutions. However, in recent years, there have been discussions and general outcry that Igbo language is neglected, endangered and near extinction due to the inversion of Western Culture and the attitudes of Ndiigbo towards the language (Ohiri-Aniche, 2008, 2014).

In teaching and learning Igbo in Secondary Schools today, a general consensus among the Igbo specialists and Ndiigbo that the performance of an average student has fallen below standard in Ebonyi State, Nigeria. This is a development that is attributable to poor performance of students in both internal and external examinations in majority of schools. The various stake-holders in Igbo language, the Igbo teachers, parents and the students and even the government are being accused of being responsible. In spite of the contributions of teachers, parents, government and even the students to their poor performance in Igbo language, researches have shown that lack of availability and utilization of instructional materials is also a potent factor. The wise teacher will always use tools or aids in form of instructional materials to help the learners understand and learn better. The unavailability of instructional materials for effective teaching in Public Junior Secondary Schools and the little or no use of the available ones have been perceived to have impact negatively on the performance of students in Igbo language at the Secondary level (Anyanwu, 2003).

Instructional materials in language teaching and learning are some of the most important devices which both the teachers and learners can use to enhance the quality of instruction in the target language. Instructional materials can be referred to as varieties of things such as; printed materials, audio, Visual and audio-visual materials which are used by the teacher to teach.Any material used by the teachers and learners to facilitate learning can be referred to as an instructional material. They have influence on what goes on in the classroom (Jones, 2009; Richards, 2010; Tomlinson, 2008; MCDonough, Shaw \& Mashura, 2013).

Instructional materials can also be defined as materials or tools locally made or imported that could make 
tremendous improvement in a lesson if judiciously utilized (Wambui, 2013). Abdul-Raheem (2016) defined instructional materials as essential and significant tools needed for teaching and learning of school subjects to promote teachers' efficiency and improve students' performance.

Instructional materials, however, do not achieve any of the attributed values on their own. Their usefulness depend on what the teacher make out of them. This infers that intelligent handling of these materials in the classroom is necessary. For effective utilization of instructional materials, teachers must understand how to use and control instructional materials. It is mandatory for the classroom teacher that uses these devices to direct the attention of students to focus on the application of the instructional materials for lesson delivery (Bassy \& AmieOgan, 2019). Instructional materials are of different types.

Cakir (2015) noted that the list of instructional materials that language teachers can use to improve learning in the language classroom is inexhaustible. He emphasized that teachers' level of resourcefulness, creativity and imagination is the limit. The types of instructional materials that are commonly utilized by teachers and learners as categorized by different scholars are as follow; Tok (2010) classified these instructional materials into two groups; printed ones such as courses books, workbooks, teachers' guides etc; and non-printed ones such as computer-based materials, videos, etc. Adelabi (2003) classified them as audio media, visual media, and audiovisual media. He defined audio media as teaching and learning devices that mostly appeal to the sense of hearing. Examples are radio, public address system, tape recorder, voice amplifier and talking drum. Visual media are teaching and learning devices that mostly appeal to the sense of seeing only, which can further be divided into projected and non-projected visuals, examples films, slides (projected), and pictures, realia and globe (nonprojected) while audio-visual media are the devices which provide the learner with the opportunity of seeing and equally hearing at the same time, examples are television, videos and film.

Correspondingly, Tomlinson (2012) classified the language teaching materials in terms of instructional purposes as follows: Informative (informing the learner about the target language); instructional (guiding the learner in practising the language); experiential (providing the learner with experience of the language in use); eliciting (encouraging the learner to use the language); and exploratory (helping the learner to make discoveries about the language).

Generally, instructional materials can be categorized in three major groups:

1. Traditional materials

2. Audio-visual material and

3. Information and communication based materials (Cakir, 2015).

According to Cakir, traditional materials could be regarded as the classic or old usually include board, course book, worksheet, charts, realia, flash card, teacher-made material etc.As for audio and visual materials which are regarded as new for many teachers, are video players, video camera, computer projection device, etc, whereas the third category of the instructional materials, widely acknowledged as the newest, is Information and Communication Technology (ICT) based materials such as computer, internet, tablets and smartphones).

The rapid advancements in technology in this $21^{\text {st }}$ century has heralded the advent of information and communication technology (ICT) based materials into language classroom. In this digital age, language teachers must cope with new challenges, responsibilities and duties. ICT based materials are the technologies used in conveying, manipulating and storing of data by electronic means which provide an array of powerful tools that may help in transforming the present inaccessible teacher-centered and text bound classrooms into rich, studentfocused and interactive knowledge environment (Chijioke, 2015).

Availability of instructional materials refers to the provision made to secondary schools for the purpose of enhancing teaching and learning using instructional materials. Adeoye \& Popoola (2011) stated that in each society, there are facilities other than classrooms that contributes in no small measure to teaching and learning process. For learning to take place, learners must have access to necessary information materials and resources to ensure some level of performance. This is because these materials help to bring about varieties which arouses and maintain the interest of the students. As Chomsky in Cakir (2015) rightly observed that $99 \%$ of teaching is to make the students feel interested in the materials. In orders to make the Igbo language more interesting for language learners, teachers should seek to find and present alternative techniques in lesson delivery by using the appropriate instructional materials in teaching and learning process.

Utilization of instructional materials is the process whereby instructional materials are systematically put into use, managed and organized, towards meeting the goal of teaching and learning. (Olagunju \& Abiona, 2008). They further added that in a school, instructional materials that are available should be utilized such that it enables the learners acquire desirable learning competencies. Utilization of standard instructional materials in teaching had been known to promote fruitful learning since it stimulates student's senses and motivates them. The successful implementation of any academic programme depends on the availability and utilization of instructional materials therefore, their presence is good predictors of a well facilitated and effective programme. Bozimo in Ikwumelu \& Oko (2015) observed that there are ever increasing number of instructional materials (audio and visual materials) available to schools. She advised that teachers should take advantage of the 
opportunities to procure excellent films and recordings covering a wide range of subject matters in school curriculum. Nevertheless, experience has shown that instructional materials are grossly inadequate in most public secondary schools in Ebonyi State therefore, cannot be utilized because one can only make use of what is available at the time it is needed. The use of instructional materials is necessary in public junior secondary schools, as it is perceived that students in public secondary schools sometimes find it difficult to comprehend immediately what is being taught by the teacher due to non availability of instructional materials to convey the concept and topics taught to the learners. This may have affected the grades of students in Igbo language in public junior secondary schools. Chijioke(2015) asserts that most of them have not been able to achieve academic success in both internal and external examinations because of perceived inadequate supply or nonavailability of instructional materials in public junior secondary schools.

\section{Purpose of the Study}

Generally, the study aimed at ascertaining the availability and utilization of instructional materials for effective teaching of Igbo language in Public Junior Secondary Schools in Ebonyi State, Nigeria. Specifically, the study was to;

1. Ascertain the adequacy of instructional materials for teaching Igbo language in Public Secondary Schools in Ebonyi State, Nigeria.

2. To find out the extent those instructional materials are being utilized by teachers in teaching Igbo language in Public Junior Secondary Schools in Ebonyi State.

\section{Research Questions}

1. How adequate are the instructional materials available for teaching Igbo language in Public Secondary Schools in Ebonyi State, Nigeria?

2. To what extent do Igbo language teachers utilize those instructional materials in teaching Igbo in Public Junior Secondary Schools in Ebonyi State, Nigeria?

\section{Methodology}

This study adopted a descriptive survey research design. A descriptive design study aims at collecting data on and describing in a systematic manner, the characteristics, features or facts about a given opinion (Nworgu, 1991). The study was conducted in Ebonyi State of Nigeria. The Population of the study was fifty two (52) Igbo language teachers in Afikpo Education Zone of Ebonyi State. There was no sampling as the entire population was used for the study. Data for the study were collected with a self-contructed instrument titled "Availability and Utilization of Instructional Materials for Teaching of Igbo Language Questionnaire (AUIMTIQ). The instrument was validated by three experts, one in Technology and Vocational Education (TVE) one expert in Igbo Language Education and one in Measurement and Evaluation from Ebonyi State University. The reliability of the instrument was established using Pearson product moment correlation. The reliability coefficient of the instrument was found to be 0.80 . The fifty two(52) copies of the instrument were administered personally by the researcher with some explanations where necessary. That ensured $100 \%$ return rate of the instrument. The two research questions were answered using the percentges, mean $(\bar{x})$ and standard deviation (SD). Items that scored 2.50 and above were deemed highly utilized while the items that scored below 2.50 were deemed lowly utilized or not utilized.

\section{Results:}

Results from the study were presented in the table below:

Research Question I:

How adequate are the instructional materials for teaching Igbo language in Public Junior Secondary Schools in Ebonyi State, Nigeria?

Table I: Percentage of Adequacy of Instructional Materials for Teaching of Igbo Language in the Public Junior Secondary Schools in Ebonyi State.

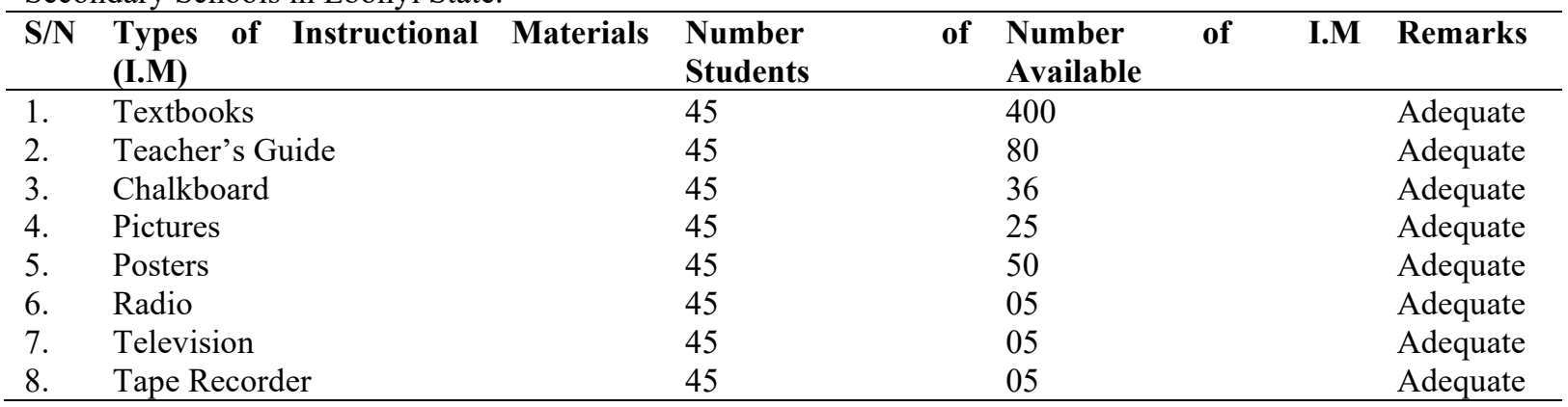




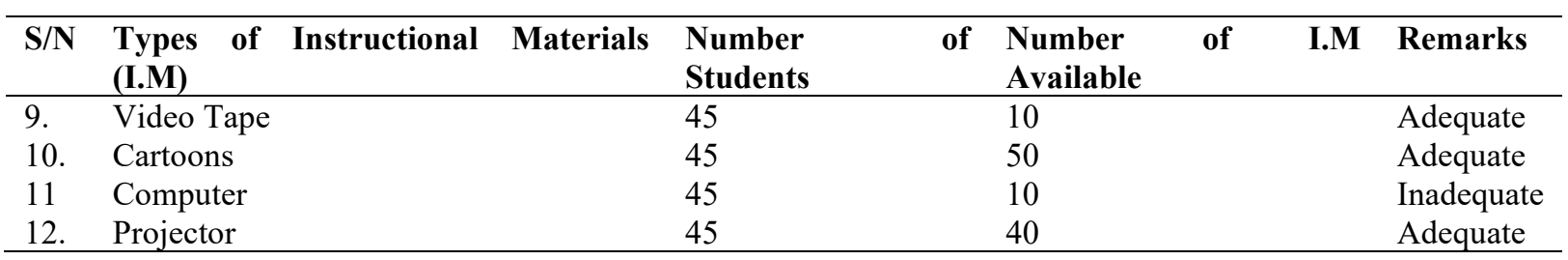

Source: Field Survey, 2019

Result from table I shows that eleven (11) instructional materials were adequate for teaching Igbo Language in Public Junior Secondary Schools in Ebonyi State, Nigeria, while one (1) instructional material (computer) was inadequate for teaching of Igbo language in public Junior Secondary Schools in Ebonyi State, Nigeria.

Research Question 2:

To what extent do Igbo language teachers utilize those instructional materials in teaching Igbo in Public Junior Secondary Schools in Ebonyi State, Nigeria?

Table 2: Mean and Standard Deviation of the respondents on the extent of utilization of instructional materials for teaching of Igbo language in Public Junior Secondary Schools in Ebonyi State.

\begin{tabular}{|c|c|c|c|c|c|c|c|c|}
\hline $\mathbf{S} / \mathbf{N}$ & $\begin{array}{l}\text { Instructional } \\
\text { Material (I.M) }\end{array}$ & $\begin{array}{l}\text { Very Highly } \\
\text { Utilized } \\
\text { (VHU)4 }\end{array}$ & $\begin{array}{l}\text { Highly } \\
\text { Utilized } \\
\text { (HU)3 }\end{array}$ & $\begin{array}{l}\text { Lowly } \\
\text { Utilized } \\
\text { (LU)2 } \\
\end{array}$ & $\begin{array}{l}\text { Not } \\
\text { Utilized } \\
\text { (NU)1 }\end{array}$ & $\operatorname{Mean}(x)$ & SD & Decision \\
\hline 1. & Textbook & 45 & 7 & - & - & 3.86 & 0.34 & VHU \\
\hline 2. & Teachers Guide & 40 & 10 & 2 & - & 3.73 & 0.52 & VHU \\
\hline 3. & Chalkboard & 37 & 10 & 5 & - & 3.61 & 0.66 & VHU \\
\hline 4. & Pictures & 6 & 10 & 10 & 26 & 1.92 & 1.08 & LU \\
\hline 5. & Posters & - & 10 & 15 & 27 & 1.67 & 0.78 & LU \\
\hline 6. & Cartoons & - & - & 22 & 30 & 1.42 & 0.49 & NU \\
\hline 7. & Radio & - & 3 & 20 & 29 & 1.50 & 0.61 & LU \\
\hline 8. & Television & - & - & 12 & 40 & 1.23 & 0.42 & NU \\
\hline 9. & Tape Recorder & - & - & 20 & 32 & 1.38 & 0.49 & NU \\
\hline 10 . & Video Tape & - & - & 10 & 42 & 1.19 & 0.30 & NU \\
\hline 11. & Computer & - & - & 12 & 40 & 1.23 & 0.42 & NU \\
\hline 12. & Projector & - & - & 7 & 45 & 1.13 & 0.34 & NU \\
\hline
\end{tabular}

Source: Field Survey, 2019.

Result from Table 2 reveals that the respondents identified three (3) instructional materials very highly utilized (Textbooks, Teachers Guide and Chalkboard), while three (3) instructional materials (Pictures, Posters and Radio) were lowly utilized and six (6) instructional materials (Cartoons, Television, Tape recorder, Video tape, Computer and Projector) were not utilized.

\section{Discussion of Findings}

The result of data analysis presented above revealed that most of the instructional materials are available and adequate for teaching of Igbo language in Public Junior Secondary Schools in Ebonyi State. This agrees with the views of Bassey and Amie-Ogan (2019) who asserts that there were adequate visual and audio instructional material for effective teaching in Public Junior Secondary Schools in Port Harcourt Metropolis, River State. Similarly, Cakir (2015) observes that basic materials, visual, audio, and audio-visual materials were adequate for teaching English language.

However, in Table 2, the study further showed that most of the instructional materials available were not utilized except the textbook, teacher's guide that are highly utilized. This is in agreement with Prodromou (1999)who pointed out that teachers do not often introduce any extraneous material into the lesson as they regard the course book (textbook) as a holy book which is not tampered with or questioned.

A general finding in this study is that most of the teachers are not so very willing to take part in teaching activities that require additional materials, effort and time. However, it is widely accepted that a single extracurricular material or activity bring a wide variety into the language classroom. Thus, in order to make Igbo language more interesting for the students, teachers should seek to find and present alternative techniques in addition to Igbo language textbooks in use.

\section{Conclusion}

From the findings, the researcher concludes that some of the instructional materials for teaching Igbo language are adequate in public junior secondary schools visited. It was equally discovered that most of the available instructional materials are not being utilized by the teachers. Information and communication Technology (ICT) based materials are markedly absent for teaching Igbo language in most of the schools visited, which in turn hindered their utilization. Igbo language teachers should endeavor to utilize other available instructional 
materials in addition to the language textbooks in use. This would facilitate the achievement of the objectives of Igbo language education as stated in the Curriculum.

\section{Recommendations}

Based on the findings of this study, the following recommendations were made;

(1) That Igbo language teachers should be made to attend seminars, workshop and conferences on utilization of instructional materials for teaching of Igbo in order to actualize the objectives of the language teaching at the Junior Secondary School level.

(2) The Ebonyi State government should provide those instructional materials not available in the schools through the ministry of education to the schools, to promote effective teaching and learning of Igbo language.

\section{References}

Abdul-Raheem, B.O. (2016). Effects of Instructional materials on Secondary Schools Students' Academic Achievement in social studies in Ekiti State, Nigeria. Journal of Current Discourse and Research, 324 325.

Adeoye, M.O. \& Popoola, S.O. (2011). Teaching effectiveness, availability, accessibility and use of Library and information resources among teaching staff of schools of Nursing in Ogun and Oyo State. Available at http//:unllib.unl.edu./lpp/.

Anyanwu, T. (2003). The Effectiveness of Instructional Material in Teaching of Social Studies in some selected post primary schools in Owerri Educational Zone, Imo State. Journal of Education and Practice, 6(2), $65-$ 78.

Bassey, L.G. \& Amie-Ogan, O.T. (2019). Availability and Utilization of Instructional Materials for Effective Teaching in Public Junior Secondary Schools in Port Harcourt Metropolis, River State. International Journal of Innovative Social \& Science Education Research 7 (3), 83 - 89.

Cakir, I. (2015). Instructional Materials Commonly Employed by Foreign Language Teachers at Elementary schools. International Electronic Journal of Elementary Education, 8 (1), 69 - 82.

Chijioke, G. (2015). An Exploration into varieties and use of Technology Media in Teaching English as A Second Language. M.Ed Dissertation. University of Lagos.

Federal Republic of Nigeria (2007). Official Gazette, 24 (94) Lagos, $15^{\text {th }}$ May.

Ikwumelu, S.N. Oko, N.O. (2015). Availability and utilization of ICT facilities in Teaching Economics in Secondary Schools in Ebonyi State of Nigeria. In Bozimo and Ikwumelu (edts.) Journal of Research and Theory in Education. 6 (3), 45 - 58.

Jones, S. (2009). A retrospective evaluation of an ELT course-book for a Korean University Conversation Course. MA TESOL/TEFL, Module 3. Available at http://www.birinngham.ac.uk

McDonough, J., Shaw, C., \& Mashura, H. (2013). Materials and Methods in ELT: A Teacher's guide (3 ${ }^{\text {rd }}$ edition). Oxford: Wiley Black Well.

Ohiri-Aniche, C. (2008). Igbo language: the danger ahead. 50\% of Igbo Children do not speak the language. Ndiigbo Journal 1 (6).

Ohiri-Aniche, C. (2014). Local languages for global citizenship: Spotlight on Science. The Vanguard.

Prodromou, L. (1999). How to be boring Teacher? English Teaching Professionals, 12, 16 - 18.

Tomlinson, B. (2008). Language Acquisition and Language Learning Materials. In B. Tomlinson (Ed.). English Language Teaching Materials 3 - 14. London.

Tomlinson, B. (2012). Material development for language learning and teaching. Language Teaching 45 (2), 143 -179 .

Tok, H. (2010). TEFL Textbook evaluation: From teachers' perspectives. Educational Research and Review, 5 (9), 508 - 517. Retrieved from http://www.academicjournals.org.

Richard, J. (2010). Curriculum approaches in language teaching: forward, central and backward design. RELC Journal. 44 (1), 5 - 33.

Wambui, S.E. (2013). Effects of use of Instructional materials on learners participation in Science Classroom in pre-school I Kine Zone Kirinyaga Country Kenya. Nairobi University Press, Nairobi. 